\title{
The quality of life conditioning with reference to the local environmental management: A pattern in Bivona country (Calabria, Southern Italy)
}

\author{
Fabio Ietto ${ }^{\text {a }}$, Francesca Salvo ${ }^{\text {b }}$, Nicola Cantasano ${ }^{\text {c, * }}$ \\ ${ }^{a}$ Department of Biology, Ecology and Earth Science, University of Calabria, Via P. Bucci, Cubo 15/B, 87036 Rende, CS, Italy \\ ${ }^{\mathrm{b}}$ Department of Civil Engineering, University of Calabria, Via P. Bucci, Cubo 45/B, 87036 Rende, CS, Italy \\ ${ }^{\mathrm{c}}$ National Research Council, Institute for Agricultural and Forest Systems in the Mediterranean, Rende Research Unit, CS, Italy
}

\section{A R T I C L E I N F O}

\section{Article history:}

Received 19 February 2014

Received in revised form

16 October 2014

Accepted 16 October 2014

Available online

\section{Keywords:}

Anthropic impact

Environmental management

Quality of life

Hedonic price analysis

\begin{abstract}
A B S T R A C T
The increasing landscape urbanization, through goods and services production, as required by people needs, is often cause of environmental decay producing a sharp decrease in quality life for resident population.

This paper aims to study some negative environmental feedbacks and the increase of geomorphological hazards in the coastal area, roughly urbanized, of Bivona country (Vibo Valentia, Calabria, Southern Italy). The analysis shows how the wrong and chaotic urban development, without any appropriate town planning scheme, has produced growing conditions of environmental decay with time. Consequently, it has been detected a decrease of prices in market estate commonly used as a marker of Human Quality Life. For this purpose, it has been applied the Hedonic model able to supply useful information about the gained or the reduced values of building industry caused by the improvement or by the worsening of environmental health conditions. The results highlight, with quantitative data, how the sustainable development of landscape must be realized through goods and services production respecting the environmental limits, in order to avoid negative territorial feedbacks able to decrease Human Quality Life. It has also been proposed a graphical representation about the trend of Human Quality Life in function of goods and services production.
\end{abstract}

() 2014 Elsevier Ltd. All rights reserved.

\section{Introduction}

This paper comes out from the knowledge that territorial development, through goods and services production to meet the wants and the needs of people, must involve an improving in $\mathrm{Hu}-$ man Quality Life intended as a pattern of wellbeing in compliance with a state of environmental health. So, the environmental system should be able to support all human activities related to social and economic development plans without being stressed in its balance (Howe, 1979). On the contrary, a strong human pressure could affect the environmental state and, in the long run, reduce its quality (Nijkamp, 1993). The essential requirement, for a proper territorial development, is a goods and services production within the environmental limits so to avoid its deterioration. These limits are expressed as "critical levels" (Nijkamp, 1993) or as "carrying

\footnotetext{
* Corresponding author.

E-mail addresses: iettofabio@hotmail.com (F. Ietto), f.salvo@unical.it (F. Salvo), cantasano@isafom.cs.cnr.it (N. Cantasano).
}

capacities" (Stankey, 1984; Pearce and Kirk, 1986; Romeril, 1990; Canestrelli and Costa, 1991; Moriani, 1991; Butler, 1996) and their exceeding affect the environmental health of an area and its economic activities (Girard, 1993). However, in this paper, the concept of "carrying capacities" means a fundamental limit for a proper territorial development able to create an increase of wellbeing and, then, of Human Quality Life. Whereas this, the proper planning of landscape development (D) should be realized as an effective summation of goods, services (here expressed as "Quantity Life" $\mathrm{Q}_{\mathrm{N}} \mathrm{L}$ ) and wellbeing chances (here expressed as "Quality Life" $\mathrm{Q}_{\mathrm{L}} \mathrm{L}$ ) within the environmental limits or in other terms: $D=Q_{N} L+Q_{I} L$.

In these last years, the fast landscape transformation, due to the increasing soil exploitation for building purposes, has determined a remarkable progress in goods production $\left(\mathrm{Q}_{N} \mathrm{~L}\right)$ for the improvement of Human Quality Life $\left(\mathrm{Q}_{\mathrm{L}} \mathrm{L}\right)$. The fast and unorganized development of human activities has often produced an overloading of the environmental sustainability limits (Nijkamp, 1993). These human actions have caused conditions of environmental deterioration triggering negative territorial feedbacks against built 
goods and resident populations. In this background, it appears a reduction in human wellbeing and then in Quality Life, appraisable through those factors estimable in economic values, as for instance the analysis of real estate prices. The temporal evolution of economic values in the real estate and, also, the relative factors could be appreciated through the application of the Hedonic model (Lancaster, 1966; Rosen, 1974, 1978; Dreze and Hagen, 1978; Bartik, 1987; Garrod and Willis, 1992; Powe et al., 1995; Adair et al., 1996 Sheppard, 1999; Pagourtzi et al., 2003). This kind of approach, able to supply useful informations about the gained or the reduced values of building industry, is caused by the improvement or by the worsening of environmental health conditions (Howe, 1993). In this respect, the used methodologies are referred to regression models but also to estimation methods such as the Market Comparison Approach (Simonotti, 2006; Appraisal Institute, 2008) and others mentioned in the International Valuation Standard (IVSC, 2007).

An application of these concepts has been conducted for Bivona country, in Vibo Valentia Province, along the Calabrian Tyrrhenian coasts (Southern Italy). In this area, it has been observed the effect of urbanization on the unstable geomorphological equilibrium during the period 1870-2010. This kind of urbanization has been performed through a raving development without any appropriate town planning scheme or often modified by human needs. Therefore, the high and unorganized production of human goods $\left(\mathrm{Q}_{N} \mathrm{~L}\right)$, which would have to produce an increased amount of human wellbeing $\left(\mathrm{Q}_{\mathrm{L}} \mathrm{L}\right)$, has triggered, contrary to expectations, a lot of negative territorial feedbacks. Amongst these, the coastal erosion and the increasing hydrogeological vulnerability represent, today, the main hazards for the extant heritage, both natural and building goods. So, territorial feedbacks are a clear expression of a Quality Life reduction $\left(\mathrm{Q}_{\mathrm{L}} \mathrm{L}\right)$ measured through the application of the Hedonic model.

The present study aims to show how a wrong urbanization, pursued through an excessive increase of Quantity Life $\left(Q_{N} L\right)$, could affect also the geomorphological delicate equilibrium, producing a reduction in Human Quality Life $\left(\mathrm{Q}_{\mathrm{L}} \mathrm{L}\right)$ estimated by analyzing real estate prices. In this work, we also suggest a new graphical representation, applicable in any human-dominated environment, in which is shown the Human Quality Life trend in function of a manmade development.

\section{Study area}

Bivona country (Fig. 1), close to Vibo Marina town, spreads out along the southern edge of Lamezia Terme Gulf on the Calabrian Tyrrhenian coasts (Southern Italy). Its town planning expansion, along a littoral stretch of about $3 \mathrm{~km}$, has remarkably increased from 1970 through the implementation of touristic resorts and residential buildings at holiday vocation. The intense urbanization of coastal stretch, occurred in the following years, particularly from 1980 to 2000, has almost joined, in the same urban conglomeration, Bivona country with Vibo Marina town, producing a slow and steady transformation of land use from tourist to residential neighborhood.

The geomorphological pattern of the studied area is marked by sandy beaches extending at the base of a hilly strip with top elevations of about $500 \mathrm{~m}$ a.s.l. The lithological outcropping is constituted by a crystalline metamorphic bedrock (gneiss rock) from Paleozoic age, belonging to the Polia-Copanello Unit (Cortese, 1895; Novarese, 1931; Nicotera, 1959; Amodio-Morelli et al., 1976; Ghisetti, 1980; Tortorici et al., 2003). This outcrop is overlaid, in transgression, by Tortonian marine sediments (Nicotera, 1959), constituted by silico-clastic layers little cemented. Continental detritic-eluvial layers and vegetal soils, of variable thickness, overlay the Tortonian sediments or are directly in contact with a crystalline basement. The lithological sequence is characterized by a weak mechanical resistance to erosion, not only for genetic factors, due to the feeble or negligible cementation in sedimentary deposits (Ietto et al., 2013), but also for some acquired features, as tectonic deformation and weathering processes in crystalline

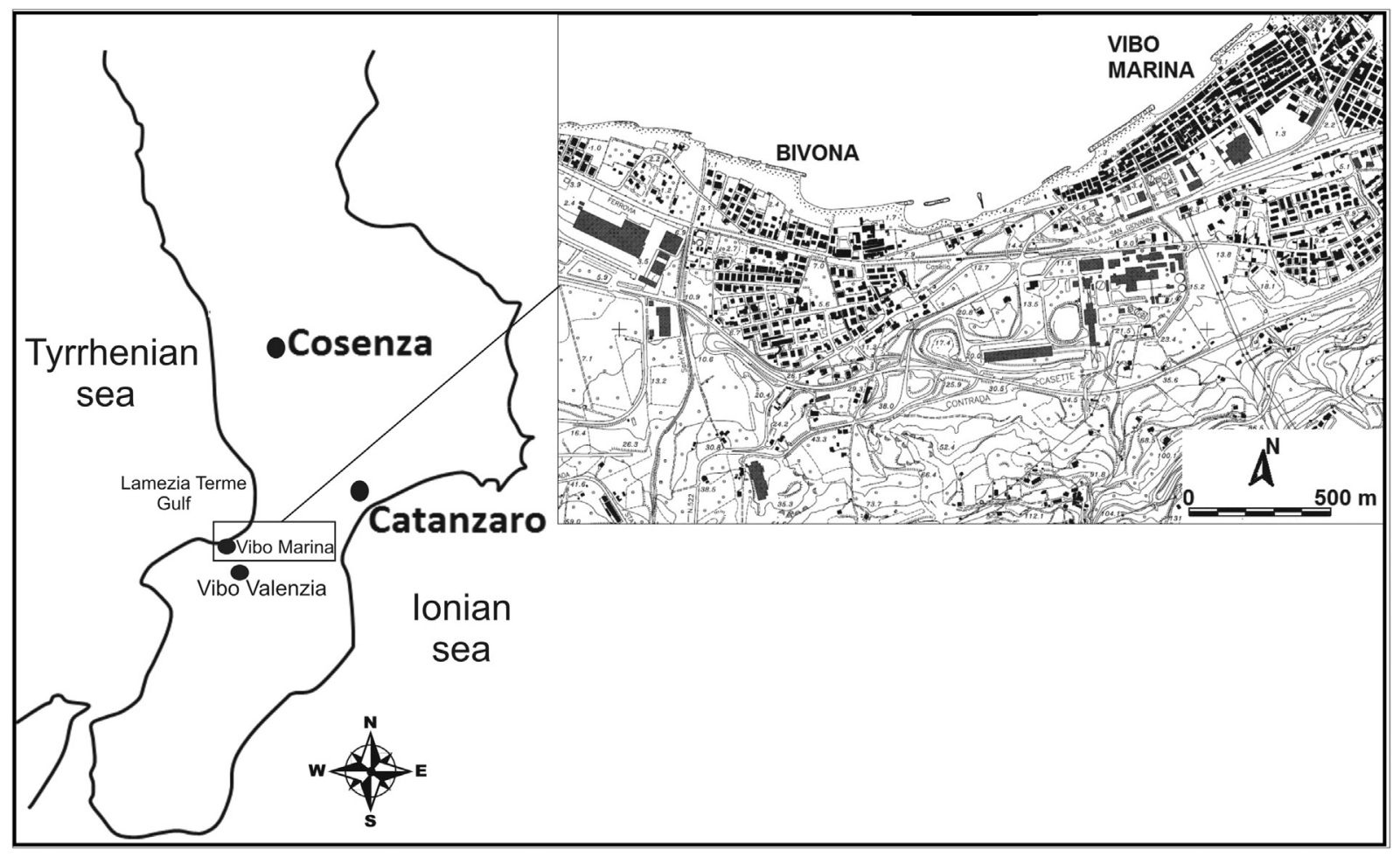

Fig. 1. Location of studied area reporting Bivona's urban area in Vibo Valentia Province (Southern Italy). 
basement (Thomson, 1994; Ietto and Ietto, 2004; Calcaterra and Parise, 2005; Ietto et al., 2007, 2012, 2014; Borrelli et al., 2007, 2012, 2014; Perri et al., 2012a, 2014). Besides, starting from the middle Pleistocene, the strong regional uplift in Calabria, still active (Miyauchi et al., 1994; Ietto and Bernasconi, 2005; Antonioli et al., 2006; Cucci and Tertulliani, 2006), is the main cause of a high erosive energy. This kind of rising is, also, one of the reasons of the rejuvenation of drainage systems, in which erosion is mostly vertical, causing steep slopes dominated by a widespread instability (Ietto et al., 2003, 2009). The juvenile stage of the hydrographic networks involves the existence of small catchments, in stream feature, with a low hierarchy degree and a high steepness both longitudinally (gradients up to $7 \%-8 \%$ ) and along the valley slopes (Ietto et al., 2009). The geomorphological pattern highlights a high susceptibility to quick and dangerous debris flows, especially during heavy rainfalls, pouring large amounts of detrital material in the straight and steeps riverbeds until the coastal area with dangerous consequences (Ietto et al., 2009; Ietto, 2012). The heavy rainfalls occurring frequently on the Calabrian Tyrrhenian coasts, due to the regional rainfall pattern, mark this region as one of the wetter countries in Southern Italy with an annual rainfall of $1151 \mathrm{~mm} /$ year against a national trend of $970 \mathrm{~mm} /$ year (Petrucci et al., 1996). The presence of some coalesced alluvial fans, on which Bivona's builtup area has recently developed, confirms the massive transport of solid materials by the hydrographic network (Ietto et al., 2009). The strong hazard condition of this area is, also, highlighted by the major rainy event of about $200 \mathrm{~mm}$ of rainfall in just three hours (Ietto et al., 2009), occurred in Vibo Marina town and in Bivona country on July 2006, triggering landslides along the slopes of catchments and floodings in the inhabited coastal areas.

The geological and geomorphological pattern, just discussed, is an environmental condition that, if properly managed, could be the main driving force for a human wellbeing in this coastal area and more exactly:

- sandy beaches well nourished by drainage channels, which collect large amounts of detritic material from erosional processes in continental areas to the sea (e.g., Perri et al., 2012b);

- coastal plains extending continually from the coastline until to the base of hilly belt;

- widespread presence of groundwater and water run-off;

- absence of dry areas and a plenty of vegetated soils.

However, the present environmental state of this coastal area is the final result of an unstable geomorphological equilibrium in which the improper use of land, related to an incorrect and confused urbanization, may produce hazard conditions disproportionate to the triggering cause. In such conditions also the occurrence of normal natural events, not necessarily exceptional, such as rainfalls, landslides, sea storms etc., may become the cause of hazard for people and built goods.

\section{Methodology of the study}

\subsection{Layering mapping}

It has been conducted a cartographic study about the morphological evolution of coastline and the urban sprawl of Bivona littoral for the period 1870-2006. The results, coming out by this urban development study, are used to value the increasing over time of "Quantity Life" $\left(Q_{N} L\right)$, while the morphological evolution of coastline has been intended as one of the possible expressions of the "environmental health" of coastal system. On this purpose, some topographic maps and orthographic photos, respectively supplied by the Military Geographic Italian Institute (I.G.M.) and by the Calabria Region, have been used, as are:

- Topographic map I.G.M. (scale: 1:50.000), dated on 1870;

- Topographic map I.G.M. (scale: 1:25.000), dated on 1960;

- Topographic map I.G.M (scale 1:25.000), dated on 1993;

- Orthographic photos (Calabria Region), dated on 2006.

The cartographic materials, referred to the same coordinate system, have been geo-referenced using the Geographic Information System "Quantum GIS 1.7.0" and, then, a digital comparison has been performed through overlapping all the elements previously computerized. This process has enabled to value the area of urban sprawl in the following temporal steps: 1870-1960; 1960-1993; 1993-2006. The same process has been used to reconstruct the evolutionary trend of the coastline, enabling to estimate the areas in erosion and/or in accretion and the implementation, on time, of breakwaters for coastal protection. For this purpose, some ground control points were chosen to ensure acceptable data, providing a maximum error in shoreline position of $\pm 5 \mathrm{~m}$.

\subsection{Price analysis in real estate sales}

The value of Human Quality Life, intended as wellbeing production respecting conditions of environmental health, has been estimated through the method of "Hedonic Price" (Lancaster, 1966; Rosen, 1974, 1978; Dreze and Hagen, 1978; Hoevangel, 1994; Saderion et al., 1994; Garrod and Willis, 1999). This method lets to assign the economic values of real estate on the basis of the usefulness attributed to each feature that make it up. In this regard, there are a lot of variables contributing to fix the price of a real estate and these data are differentiated in relation to the various kind of property market. Thus, it is impossible to establish the economical values of a market price beforehand. Therefore, it is necessary, not only, to analyze the real estate prices but, also, to examine the different features affecting their values to establish a statistical forecasting survey of the market values.

In this paper, amongst the different methods generally used for the estimation of Hedonic Prices, it has been adopted a multiple linear regression analysis that enables to point out the variations in estate values (depending fluctuations) according to its features (independent fluctuations). The multiple regression analysis is a statistic tool, widely spread, applied to economic estimating appraisals (Bruce and Sundell, 1977). This data processing allows to establish: a) correlation between the real estate market price and all the features affecting this value; $b$ ) mutual relations between the different features valued and the quantitative effect exerted by each feature on price; c) estimate of price according to the basic principles of data processing realized by a function that, better than others, approaches to the same data.

In regression appraisal analysis, the unknown quantities are represented by the estimated values of real estate prices and by the variable rates depicting specific Hedonic prices. These last ones show the real estate market price variations in according to the increased or decreased value of each feature regarded. Therefore, these prices are considered "implicit" because concealed in the estate market and related to some indivisible features, often connected with each other, of the real estate. The definition "implicit prices" indicate, as known, only the final price because it is unknown the real connection of the invisible features with the final price of the real estate. Through the estimation of Hedonic prices, it is possible to value the monetary contribution of each variable to the final market price of the real estate valued (Dunford et al., 1985). 
In the case study of Bivona's built-up area, in Vibo Valentia Province, 90 purchase prices of flats have been detected in the period 1973-2010. It was impossible to increase the period of the survey because historical purchase prices are unavailable. In fact, before 1973, the practice to create a real estate data set was uncommon. The real estate sample regarded is made up by condominium apartments located along the coastline and placed in the same area, so exceeding locational factors. The data collection was realized using specific tabs that have enabled, for each apartment, the census of the following features:

1) locational: concerning the position of the apartment in the urban context (facilities, services, etc...);

2) positional: concerning the position of the apartment in the condominium (floor level, exposition, etc...);

3) typological: concerning the features of the apartment (surfaces, maintenance conditions, plants, etc...);

4) economical: concerning the conditions and the restrictions in estate use (free or leased, constraints, etc...);

5) financial: concerning the forms of financing for costumers;

6) institutional: concerning the law framework (taxations, benefits, etc...).

For each sampled apartment it has been, also, detected its real price in the transaction (total price) and its main estate features, as reported below:

- transaction date (DAT);

- commercial surface in square meters (SUR);

- restrooms number (RES);

- floor level (FLO);

- distance to sea in meters (DIS).

Among the real estate features, used for the appraisal, have been valued only the characteristics affecting the market price. In this specific case, these ones are the only features different in the final amount, while the other characteristics, locational, positional and economic are equal in the amount and, therefore, unaffecting the market price formation of the property. Obviously, between the considered individual real estate features, none is able to represent, directly, the conditions of the Human Quality Life. Therefore, this latter is not considered as an independent variable in the multiple regression method, but comes out from the set of many variables that make up the total economic value of the property which, represents how the buyers evaluate the quality conditions and the wellness deal of the property. Knowing the real estate prices function and their evolution in time is, therefore, useful to have more informations about the change of environmental quality

Table 1

Statistical table of the real estate registered in Bivona.

\begin{tabular}{|c|c|c|c|c|c|}
\hline Statistics & Minimum & Maximum & Media & Frequency & $\begin{array}{l}\text { Standard } \\
\text { deviation }\end{array}$ \\
\hline Total price $(€)$ & $12,000.00$ & $80,000.00$ & $46,777.78$ & - & $27,761.38$ \\
\hline $\begin{array}{l}\text { Average price } \\
\text { PRCA ( } € / \text { sqm })\end{array}$ & 101.69 & 775.19 & 462.33 & - & 272.99 \\
\hline $\begin{array}{l}\text { Commercial surface } \\
\text { (SUR) (sqm) }\end{array}$ & 97.4 & 118 & 102.24 & - & 6.57 \\
\hline $\begin{array}{l}\text { Restrooms } \\
\quad(\text { RES })\left(n^{\circ}, 1-2\right)\end{array}$ & 1 & 2 & - & $8-1$ & - \\
\hline $\begin{array}{l}\text { Floor level } \\
\quad\left(\text { FLO) }\left(1^{\circ}, 2^{\circ}, 3^{\circ}\right)\right.\end{array}$ & 1 & 3 & - & $3-4-2$ & - \\
\hline $\begin{array}{l}\text { Distance to } \\
\quad \text { sea (DIS) (m) }\end{array}$ & 5 & 870 & 365 & - & 320.36 \\
\hline
\end{tabular}

conditions (Howe, 1993) and so of the Human Quality Life. In Table 1, the main sample statistics are reported.

The set of census data has been analyzed by multiple regression method and by price's equation theoretically expressed by a linear progression, as in the following expression:

$y_{j}=b_{0}+b_{1} \cdot x_{j 1}+b_{2} \cdot x_{j 2}+\ldots+b_{n} \cdot x_{j n}$

where:

$y_{j}=$ dependent variable (sale price of generic real estate $j$ );

$x_{j i}($ with $i=1,2, \ldots, n)=$ features considered significant;

$b_{i}=$ Hedonic prices of the valued features.

This equation has enabled to obtain, year by year, the average unit prices, through which it has been possible to value the indexes numbers of the real estate prices $\left(I_{t}\right)$, considering the year 1973 as the reference base. Therefore, the indexes numbers have been calculated on the base of the arithmetic mean of total prices, for each year, and on the base of the arithmetic mean of the corresponding areas. In particular, the indexes numbers $\left(I_{t}\right)$ have been estimated traditionally by the following formula:

$I_{t}=\mathrm{PRCA}_{t} / \mathrm{PRCA}_{0}$

where:

$\mathrm{PRCA}_{t}$ is the estimated value of unit price at time $t$

$\mathrm{PRCA}_{0}$ is the estimated value of unit price at the reference time.

The indexes numbers of estate price $\left(I_{t}\right)$, calculated in this way, represent the numerical indicators useful to the comprehension of real estate returns. These numbers enable to represent their rates as a result of the continuous and systematic revaluation/devaluation of market prices from 1973 to 2010. Therefore, indexes numbers could be considered transaction based (Case and Quigley, 1991).

\section{Results}

\subsection{Layering mapping}

The cartographic comparison, for the periods: 1870-1960, 1960-1993, 1993-2006, has enabled to reconstruct shoreline evolution and to assess areas in erosion or in accretion along the coastal stretch of Bivona country. It has also been measured, in the same periods, the growth of urbanized areas and the extension of littoral areas protected by breakwaters.

The results of cartographic comparison are illustrated in histogram of Fig. 2 and are summarized in specific data reported in Table 2. The data show that, in time range 1870-1960, the urbanized surface, missing in 1870 , has increased by about $17,370 \mathrm{~m}^{2}$. In same range time, the study of shoreline evolution has revealed a sharp preponderance in accretion processes. In particular, along a coastline of about $3 \mathrm{~km}$, the variation in surface of coastal area showed an erosion of $-57,400 \mathrm{~m}^{2}$ and a progradation of $+76,350 \mathrm{~m}^{2}$. The positive sediment balance in coastal area, with small stretches in deficit, highlights the presence of a coastal system still flexible and well nourished by fluvial sedimentary transport. In the subsequent period investigated 1960-1993, the littoral area has been affected by a high increase in urbanization, for a total of $22,650 \mathrm{~m}^{2}$ and by a considerable erosion of beach areas equal to $-155,540 \mathrm{~m}^{2}$ with some coastal stretches in accretion equal to $+24,000 \mathrm{~m}^{2}$. In this time lag, the comparison between littoral areas in erosion and in accretion shows a clear reversal trend of sedimentary budget, with strongly negative values, confirming a 


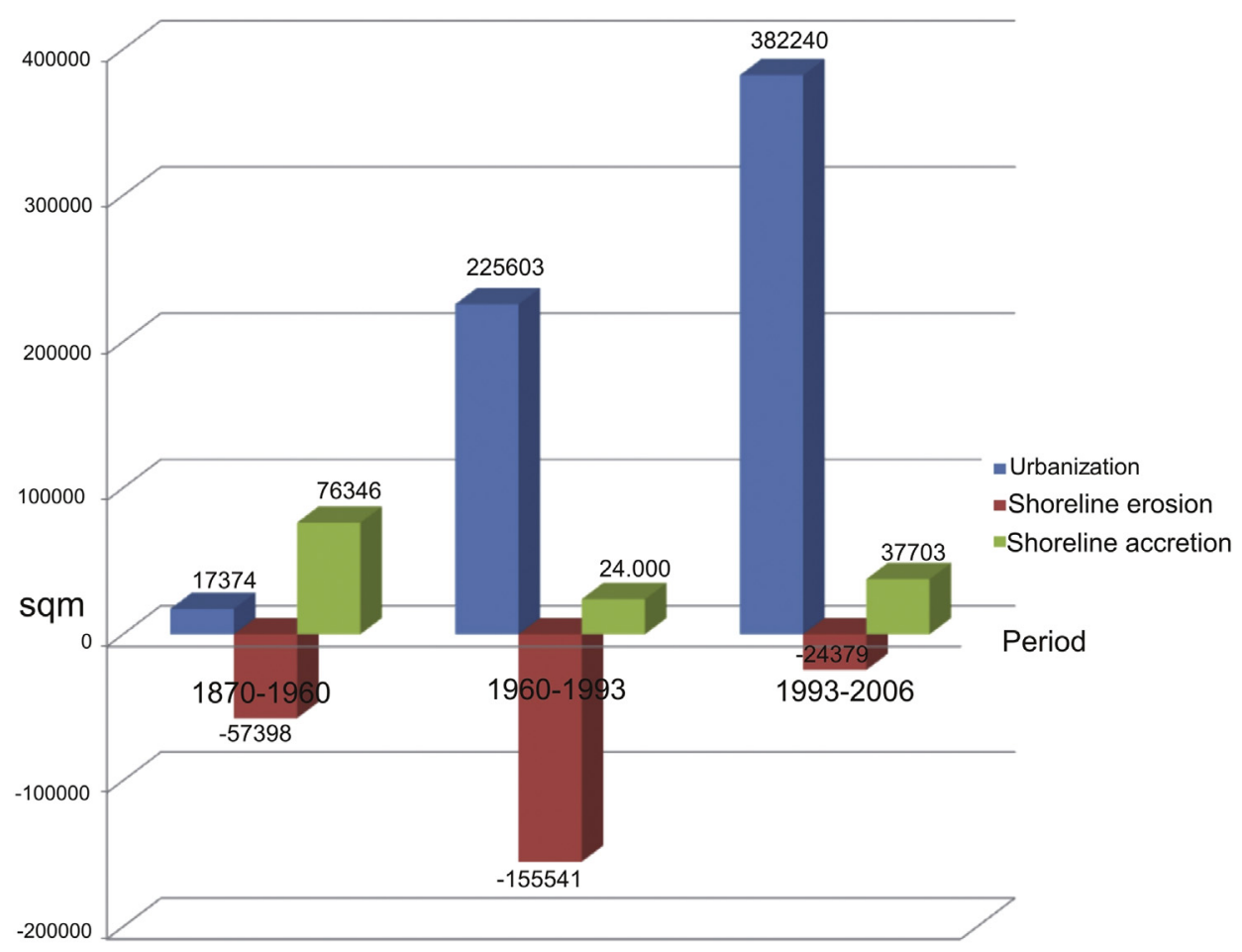

Fig. 2. Urban growth and coastline evolution between 1870 and 2006 years for Bivona's built-up area.

poor sedimentary nourishing of coastal system. In the same period, the first breakwaters against coastal erosion have been realized protecting $500 \mathrm{~m}$ of sandy beaches. In the period 1993-2006, the urbanized surface covered an area of $382,240 \mathrm{~m}^{2}$ while the breakwaters, for coastal protection, extended for a length of $1760 \mathrm{~m}$, as $57 \%$ of the Bivona's littoral. Therefore, this coastal protection system of coastal protection has produced an artificial stabilization of the coastline, as highlighted by the following data: $+37,700 \mathrm{~m}^{2}$ littoral area in accretion and $-24,380 \mathrm{~m}^{2}$ littoral area in erosion.

\subsection{Market values of real estates}

For better achieving the function of the real estate price, have been applied linear regression, not linear and logarithmic models. Among these, linear patterns were the best of all the tested models and more than others matched with the criteria of multiple regression model. In this regard, the linear regression multiple analysis, applied to real estate prices of ninety flats in the period 1973-2010, has enabled to formulate an estimate function related to the average unitary prices (PRCA) and to the Hedonic prices of estate features.

In the linear model the depreciations and the allowances of estate features (DAT, RES, FLO, DIS) show directly the Hedonic prices. Therefore, the estimate function of the average unitary price (PRCA) has been expressed by the following formula:

$$
\begin{aligned}
\text { PRCA }= & 635.15\left(€ / \mathrm{m}^{2}\right)-8.20\left(€ / \mathrm{m}^{2}\right) \cdot \text { DAT } \\
& +146.80\left(€ / \mathrm{m}^{2}\right) \cdot \mathrm{RES}+2.35\left(€ / \mathrm{m}^{2}\right) \cdot \text { FLO } \\
& +\left(-1.31\left(€ / \mathrm{m}^{2}\right) \cdot \mathrm{DIS}\right)
\end{aligned}
$$

In particular: the intercept equal to $653.15\left(€ / \mathrm{m}^{2}\right)$ represents the average unitary price in 2010 year; the Hedonic price of DAT feature (transaction date) points out that the real estate is revalued annually for $8.20\left(€ / \mathrm{m}^{2}\right)$; the Hedonic price of RES feature (restrooms number) points out that the real estate is revalued of $146.80\left(€ / \mathrm{m}^{2}\right)$ for every bathroom included in flat; the Hedonic price of FLO feature (floor level) points out that the real estate is revalued of $2.35\left(€ / \mathrm{m}^{2}\right)$ by increasing level floor; the Hedonic price of DIS feature (distance to sea in meters) points out that the real estate value increases of $1.31\left(€ / \mathrm{m}^{2}\right)$ by decreasing its distance from the sea.

The estimate function adopted is representative of the analyzed case as gets through the following check tests: $s^{2}, R^{2}, t$ and $F$ (Brown, 1974), where:

1) the standard error $s^{2}$ shows the difference between observed data and interpolated data by the model and it represents a measure of narrowness in the relationship between variables;

2 ) the correlation coefficient $R^{2}$ estimates the model ability to reproduce the original data;

3 ) the test $t$ shows the statistical importance of each variables, by which this coefficient can be tested against the null hypothesis of randomness;

4) the test $F$ rises from the corresponding variance analysis and allows to establish whether the variance, calculated by the regression method, is statistically significant or could be assigned randomly.

The results obtained by application of estimate function has enabled to reconstruct, for each year, the values of the average unitary price (PRCA) and the corresponding index number $\left(I_{t}\right)$, as reported in Table 3.

Once reconstructed the historical series of market prices, it has been possible to highlight the trend of interest market segments. Particularly, the numerical index analysis, based on the values of media unitary prices, shows a conflicting trend of the market estate, with an upward gradient until 2000 and a slight decrease until 2010. Indeed, from 1973 to 2000, it has been detected a constant 
Table 2

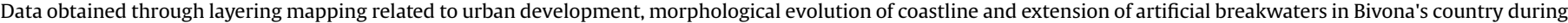
the period $1870-2006$.

\begin{tabular}{|c|c|c|c|c|}
\hline Range & Urbanization (sqm) & Shoreline erosion (sqm) & Shoreline accretion (sqm) & Artificial breakwater (m) \\
\hline $1870-1960$ & 17,370 & $-57,400$ & 76,350 & 0 \\
\hline $1960-1993$ & 225,600 & $-155,540$ & 24,000 & 500 \\
\hline 1993-2006 & 382,240 & $-24,380$ & 37,700 & 1760 \\
\hline
\end{tabular}

Table 3

Estimative results of the real estate, for each year, in the period 1973-2010.

\begin{tabular}{|c|c|c|c|c|c|}
\hline Year & Average unitary price PRCA ( $€ /$ sqm) & Index number $I_{t}$ (reference year 1973) & Year & Average unitary price PRCA ( $€ /$ sqm) & Index number $I_{t}$ (reference year 1973) \\
\hline 1973 & 178.39 & 100 & 1992 & 666.22 & 373.46 \\
\hline 1974 & 200 & 112.11 & 1993 & 686.63 & 384.9 \\
\hline 1975 & 219.22 & 122.88 & 1994 & 700.04 & 392.42 \\
\hline 1976 & 239.63 & 134.33 & 1995 & 747.46 & 418.99 \\
\hline 1977 & 255.04 & 142.97 & 1996 & 767.87 & 430.44 \\
\hline 1978 & 270.45 & 151.61 & 1997 & 788.28 & 441.88 \\
\hline 1979 & 300.86 & 168.65 & 1998 & 828.69 & 464.53 \\
\hline 1980 & 331.28 & 185.7 & 1999 & 830.99 & 465.82 \\
\hline 1981 & 311.69 & 174.72 & 2000 & 825.45 & 462.71 \\
\hline 1982 & 342.1 & 191.77 & 2001 & 800.93 & 448.97 \\
\hline 1983 & 352.51 & 197.6 & 2002 & 798.39 & 447.55 \\
\hline 1984 & 412.92 & 231.47 & 2003 & 786.56 & 440.91 \\
\hline 1985 & 453.34 & 254.12 & 2004 & 777.02 & 435.57 \\
\hline 1986 & 473.75 & 265.56 & 2005 & 760.59 & 426.36 \\
\hline 1987 & 484.16 & 271.4 & 2006 & 765.8 & 429.28 \\
\hline 1988 & 494.57 & 277.24 & 2007 & 740.38 & 415.03 \\
\hline 1989 & 500.99 & 280.83 & 2008 & 750.81 & 420.88 \\
\hline 1990 & 545.4 & 305.73 & 2009 & 720.47 & 403.87 \\
\hline 1991 & 665.81 & 373.23 & 2010 & 715.1 & 400.86 \\
\hline
\end{tabular}

increase in the economic values of real estate with a revaluation of about $+370 \%$. In the following years, from 2000 to 2010, the analysis of market values appears fluctuating and it is marked by slight increases and decreases in real estate prices. However, the overall trend of real market indicates a fall in prices and a reversal of its trend respect to 2000 with a depreciation of $-11 \%$. For instance, a specific devaluation of real estate economic value, of about $-7 \%$, has been observed only in the period 2006-2010. In Fig. 3, it has been reported through a diagram showing the economic trend of estate values in the survey period 1973-2010.

\section{Discussion}

The data analysis aims to prove as an unorganized urbanization in the coastal area, can modify its unsteady geomorphological equilibrium triggering, sometimes, new and/or extreme phenomena to reach new balance conditions. These territorial feedbacks to an improper urbanization are expression of a worsening in the environmental state, able to produce unforeseen issues or high hazard conditions to environmental and built goods. The final result is a reduction in Human Quality Life estimable, also, through the appraisal of real estates.

The study on urban development of Bivona's hamlet highlights that, from 1870 to 2006, it was built on area of $382,240 \mathrm{~m}^{2}$ (Fig. 4), with a heavy increase of buildings in the decade 1970-80. This trend is in accordance with the coastal urban development occurred in Calabria during the period 1970-1990 in which there was a sharp increase in housing (about $+61.6 \%$ ) along the Tyrrhenian coast within $200 \mathrm{~m}$ from the sea (Greco et al., 1995).

The urban development of Bivona's built-up area, occurred without any appropriate urban planning, has produced a confused overbuilding of landscape, highlighting a high local vulnerability to landslides and flood events (Ietto et al., 2009). Particularly, many tourist and residential resorts have been built in riverside areas or within fluvial beds, which have been buried in undersized water piping. Further implementations of road and railway networks, running parallel and close to coastline, have produced several bottlenecks along the river pathways, obstructing the normal flow of waters. Besides, in order to protect built-up areas, the watercourses have been strictly bound by hydraulic works as: artificial riverbanks, bridles and, sometimes, cementation of riverbeds, especially in river mouths more densely populated. These works have produced, year by year, a gradual reduction until an almost total loss of river solid transport to the sea, with a consequent poor nourishment of coastal system. The building of residential resorts, until upper limit of backshore, has produced the total destruction of dune system and the interruption of the natural shoreline dynamic equilibrium. The direct consequence has been the progressive deterioration of the unsteady coastal morphological balance and, accordingly, a reversal in shoreline trend evolution: in accretion until 1960 and in clear erosion from 1993. In the following years, until 2006, urbanization of coastal area has further increased while morphological evolution of shoreline has been rather stable following the construction of a coastal defence system along a strip of $1760 \mathrm{~m}$, corresponding to about $57 \%$ of littoral fringe. These works, even if useful to reduce coastal erosion, have produced negative impacts on landscape and into backshore ecosystem. Indeed, our recent studies on backshore sands, protected by artificial breakwaters, have demonstrated the prevalent presence of typical continental arthropods taxa instead of coastal ones, due to the absence of washing action on sands by waves (Ietto et al., 2009). This data reveal a high deterioration state into the backshore ecosystem.

Another detected effect, resulting from a confused urbanization, has been the increase of hydraulic vulnerability by flooding events in an area subjected to heavy rainfalls. Indeed, a specific contribution to the increasing of hydraulic hazard has been the presence of unsuitable buildings that have produced bottlenecks, 


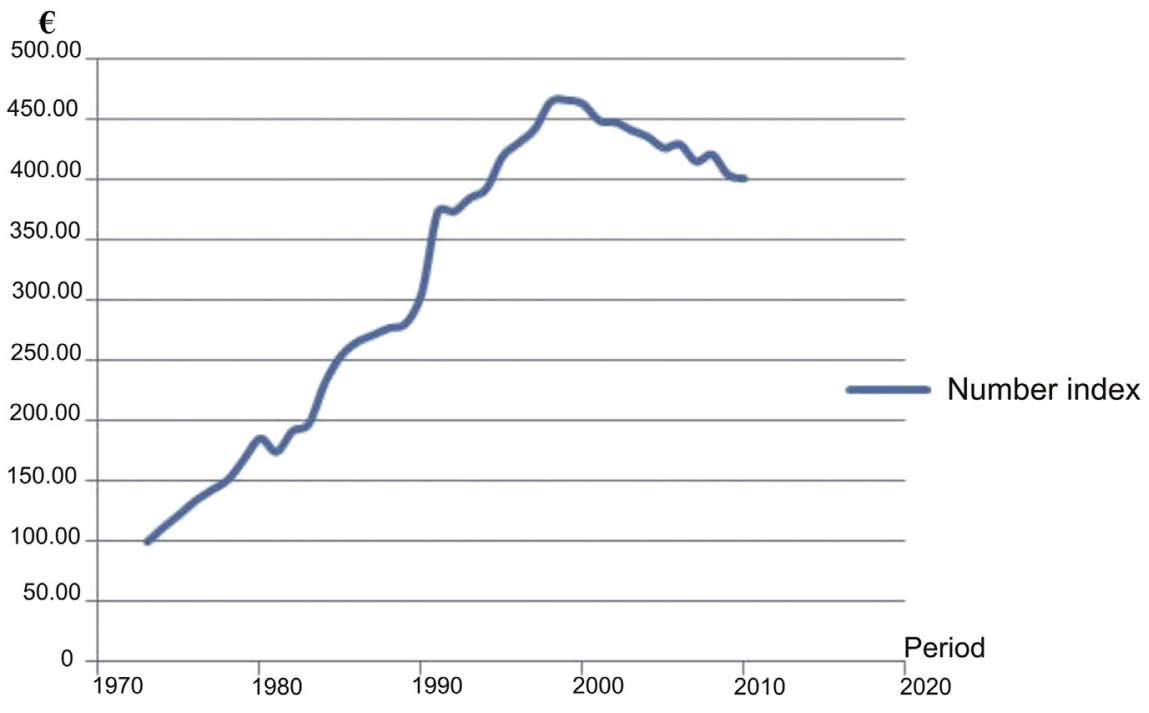

Fig. 3. Trend of the real estate market values in Bivona's hamlet in the period 1973-2010.

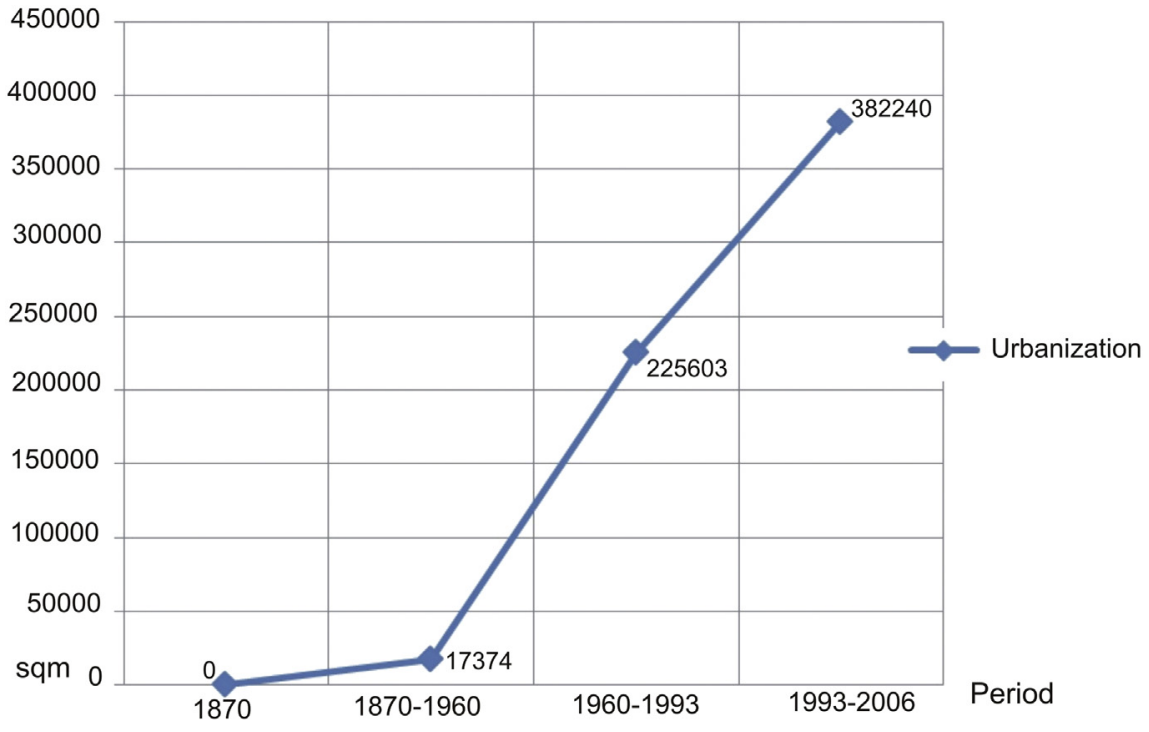

Fig. 4. Urban growth of Bivona's coastline in the period 1870-2006.

obstructions and burials of fluvial networks, blocking the normal flow of waters and increasing the flooding likelihood in densely populated areas (Ietto et al., 2009).

Evidence of such phenomena was the rainfall event occurred on July 2006, which has affected Bivona's built-up area, producing widespread landslides with a high supply of sediment into riverbeds and making inadequate the drainage network principally in urbanized coastal areas. As a direct consequence, there was the flooding of inhabited areas causing heavy damages, for a total amount of 17 million Euros and the death of four persons.

Coastal erosion, deterioration of backshore ecosystem and increase in hydraulic hazard into Bivona's coastal area, could be considered as negative feedbacks due to an incorrect urban development and, therefore, expression of a general environmental decay. In this context, it is evident the wrong environmental management lacking of any "holistic approach", that could be able, instead, to connect the right management of natural processes with a growing social and economic development (Kelleher and Kenchington, 1990).
The bad conditions of the environmental health state have directly affected the evolution of real market estate, as stated by the estimative analysis of selling prices properties surveyed. Indeed, data analysis, reported in Fig. 3, shows that in the period 1973-2000 there was a revaluation of estate values of about $+370 \%$. In the following years, until 2010, the estate prices are aligned on a decreasing trend, showing an overall devaluation of about $-11 \%$ reflecting the negative effects of local environmental decay. Noteworthy, is the marked depreciation of estate values in the period 2006-2010 in reply to the flood event occurred on July 2006.

The data analysis shows how the trend of market estate is heavily influenced by the local conditions of environmental health, as suggested by some Authors (Howe, 1993; Girard, 1993; Geoghegan, 2002; Bengochea-Morancho, 2003; Jim and Chen, 2006 and many others). Therefore, the values, obtained through an estimative analysis of the real estate prices, could be used for a quantitative assessment of environmental health state and, at the 


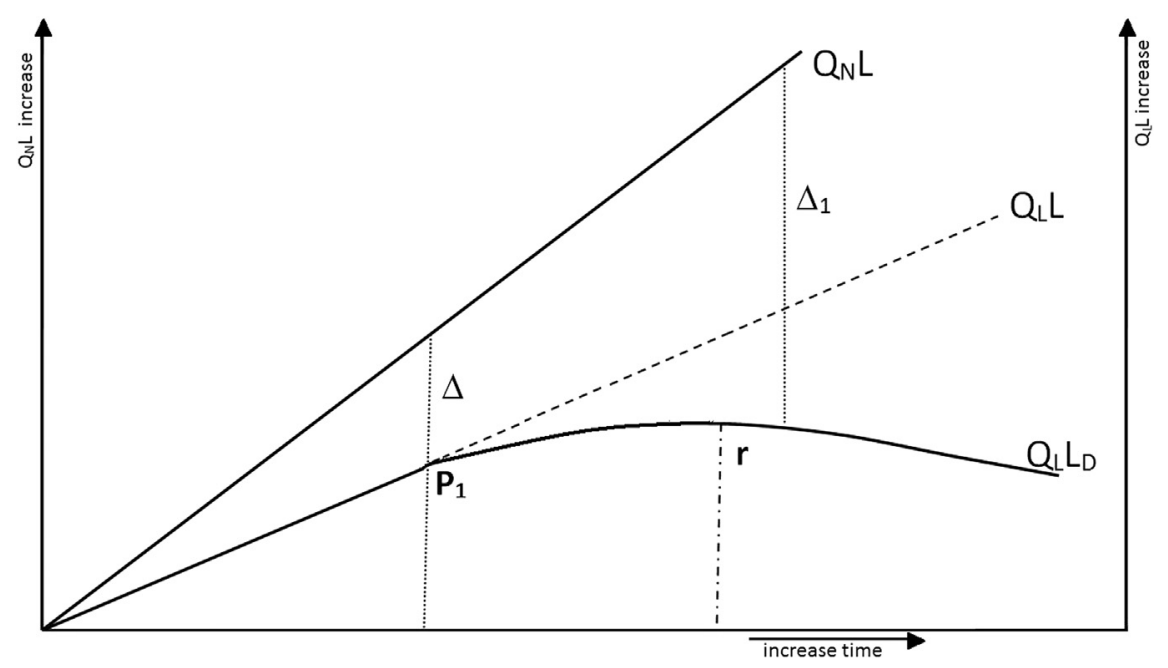

Fig. 5. Human Quality Life evolution $\left(Q_{L} L\right)$ in urbanized area, related to the high and the incorrect production of goods $\left(Q_{N} L\right)$.

same time, for an assessment of the human wellbeing (Quality Life), as it is dependent by the same environmental conditions.

It should be noted that, in the present paper, we have considered only the most evident territorial features capable to influence the Human Quality Life conditions. This choice aims to highlight how wrong urbanization may trigger negative geomorphological feedbacks able to influence the wellbeing of a place and then the $\mathrm{Hu}-$ man Quality Life. Therefore, it is not excluded that other features might affect Human Quality Life, as for example: pollution, urban congestion, overcrowding, etc...

\subsection{Graphic representation of Human Quality Life related to human activities}

Urban green spaces, water bodies and principally good environments provide amenities and services that contribute fundamentally to improving the Human Quality Life in urban sites (Shafer et al., 2000; Hidano, 2002; Van Herzele and Wiedemann, 2003; Chiesura, 2004). Their importance to the wellbeing of cities and citizens is, often, neglected in mainstream urban planning and policy making related to development (More et al., 1988; Luttik, 2000; Tyrväinen and Miettinen, 2000; Tajima, 2003; McConnell and Walls, 2005). Due to their unpriced nature and largely intangible benefits, their contribution or lack thereof is usually difficult to assess and quantify. In this regard there is a substantial literature that examines the relationships between economy and environmental health. This literature has shown that estimates of environmental and human health can be inferred from a wide variety of market situations. Various approaches have been proposed and tested, amongst which the Hedonic pricing method (Rosen, 1974) has been widely applied to estimate the value of quality environmental associated with human settlements. For instance, the impacts of green spaces situated within and near a development sites are examined for their impacts on housing price and to construct a housing price index (Anderson and Cordell, 1988; Willis and Garrod, 1993; Chattopadhyay, 1999; Bolitzer and Netusil, 2000; Luttik, 2000; Tyrväinen and Miettinen, 2000; Geoghegan, 2002; Bengochea-Morancho, 2003; Ouyang and Wang, 2003; Price, 2003). Significant negative effects on housing values have been found to be associated with hazardous waste sites (Gayer et al., 2000), water pollution (Leggett and Bockstael, 2000), air pollution (Chay and Greenstone, 2004), pediatric leukemia risk (Davis, 2004), high urban development (Jim and Chen, 2006) and many others.
In the present paper, in according with literature, we have analyzed, through Hedonic method (Rosen, 1974), the negative effects on environmental health arising by fast and unorganized urban growth. The obtained data show how the trend of market estate is influenced by deteriorating condition of local environment. In fact coastal erosion, deterioration of backshore ecosystem and flood events represent the negative feedbacks to improper urbanization and their occurrence coincides with decline of real estate prices. The latter have been used to quantify the Human Quality Life trend in function of urban growth.

The concepts discussed in the present study are qualitatively presented in graphical of Fig. 5, applicable for any humandominated environment. In the suggested diagram the term $\mathrm{Q}_{\mathrm{N}} \mathrm{L}$ represents the Quantity Life expressed as the sum between goods and services production. The term $\mathrm{Q}_{\perp} \mathrm{L}$ refers to Human Quality Life, intended as wellbeing creation within environmental limits and detectable by one or more factors estimated in market prices. The broken line $\mathrm{Q}_{\mathrm{I}} \mathrm{L}$ represents, in a correct development policy, the potential growth of Human Quality Life $\left(\mathrm{Q}_{\mathrm{I}} \mathrm{L}\right)$ obtainable by the production of goods and services $\left(Q_{N} L\right)$ within environmental limits. On the contrary, in a context of high production of $\mathrm{Q}_{\mathrm{N}} \mathrm{L}$, beyond the environmental limit of sustainability, negative territorial feedbacks might cause a reduction over time of environmental quality and, accordingly, of Human Quality Life. In the diagram of Fig. 5 it is possible to observe that the difference $\Delta$, between $\mathrm{Q}_{N} \mathrm{~L}$ and $\mathrm{Q}_{\mathrm{L}} \mathrm{L}$ terms, increases over time, until becoming inversely proportional $\left(\Delta_{1}\right)$ when excessive growth in $Q_{N} L$ occurs. In this condition, it is possible to observe an increase of $Q_{N} L$ and a decrease of $\mathrm{Q}_{\mathrm{I}} \mathrm{L}$, as represented by the bell-shaped curve $\mathrm{Q}_{\mathrm{I}} \mathrm{L}_{\mathrm{D}}$. The beginning of the parabolic curve $Q_{L} L_{D}$ is the point $P_{1}$. This point represents an exceeding of the environmental use, beyond threshold values, when the negative territorial feedbacks begin to appear. The inflection point in $\mathrm{Q}_{\mathrm{L}} \mathrm{L}_{\mathrm{D}}$ curve, represented by point $r$, could indicate the threshold limiting value of environmental resilience; namely the point in which the human-dominated environment is still able to recover itself once stopped anthropic activity. Then, exceeding of point $r$ represents a critical condition where the negative territorial feedbacks cannot recede by itself, producing a steady decrease in environmental quality and, so, in Human Quality Life.

\section{Conclusions}

The multidisciplinary study on morphological evolution of coastline, on hydraulic hazard, on urban growth and on estimative 
analysis of the real estate values in coastal area of Bivona country, has enabled to reconstruct their evolutionary trend and to detect the relationships between the respective changes over time. Indeed, data analysis has enabled to recognize an inversely proportional behavior between the growing urban development of this coastal area and the morphological evolution of its coastline. In this regard, the use of artificial breakwaters in order to control coastal erosion, though it has been partially effective, has produced a negative impact on the littoral landscape and the deterioration of backshore ecosystem. Another effect of urban growth is represented by the increase of hydraulic hazard in inhabited coastal areas, as confirmed by the last flood event in 2006. Therefore, coastline erosion, deterioration of backshore ecosystem and increase of local hydraulic hazard, represent clear examples of territorial negative feedbacks due to an incorrect urbanization, highlighting a decrease in the state of environmental health. So, the worsening of environmental health becomes the main cause of Human Quality Life reduction. The quantitative evaluation of "Quality Life" conditions has been assessed through the Hedonic Analysis of estate values, which highlights the decreasing values of market estate to the occurrence of environmental decay phenomena.

It should be specified that, even though the real estate estimative analysis is quite limited in time, in comparison to natural events observed, the obtained results are, however, meaningful. At the same time, the territorial feedback analysis, able to establish the environmental health state, could be greater than those regarded in this present work.

Furthermore, the quantitative data, surveyed for Bivona's builtup area, seem to confirm the reliability of diagram suggested in Fig. 5. In particular, the Quantity Life expression, represented by $\mathrm{Q}_{\mathrm{N}} \mathrm{L}$ curve, has been reconstructed through the data of urban growth in the period 1870-2006 (Fig. 4). The trend of Quality Life over time, represented by $\mathrm{Q}_{\mathrm{L}} \mathrm{L}$ curve in Fig. 5, has been assessed through the analysis of economic values of the real estate (Fig. 3), reconstructed only for the period 1973-2010 owing to the lack of historical data. The comparison between these two curves highlights that, opposite of prevailing growth in Quantity Life up to 2006, occurs over time a decrease of Quality Life (in growth from 1973 to 2000), with negative values of about $-11 \%$, during the period 2000-2010 $\left(\mathrm{Q}_{\mathrm{L}} \mathrm{L}_{\mathrm{D}}\right)$. This fall corresponds to the occurrence of negative environmental feedback caused by an improper urbanization, as reported in dot P1 (Fig. 5). Therefore, this multidisciplinary study highlights the functionality of the suggested diagram demonstrating by quantitative data how an incorrect policy of urban development affects the environmental health and the Quality Life of a country.

\section{Acknowledgments}

The authors would like to express gratitude to Miss Aurora Skrame, native English, for his review to manuscript. The authors also thank referees of this journal for their constructive comments and suggestions on the manuscript.

\section{References}

Adair, A.S., Berry, J.N., McGreal, W.S., 1996. Hedonic modelling, housing submarkets and residential valuation. J. Prop. Res. 13, 67-83.

Amodio-Morelli, L., Bonardi, G., Colonna, V., Dietrich, D., Giunta, G., Ippolito, F. Liguori, V., Lorenzoni, S., Paglionico, A., Perrone, V., Piccareta, G., Russo, M., Scandone, P., Zanettin-Lorenzoni, E., Zuppetta, A., 1976. L'arco calabropeloritano nell'orogene appenninico-maghrebide. Mem. Soc. Geol. It. 17, 1-60.

Anderson, L.M., Cordell, H.K., 1988. Influence of trees on residential property values in Athens, Georgia (USA): a survey based on actual sales price. Landsc. Urban Plan. 15, 153-164.
Antonioli, F., Ferranti, L., Lambeck, K., Kershaw, S., Verrubbi, V., Dai Pra, G., 2006 Late Pleistocene to Holocene record of changing uplift rates in southern Calabria and northeastern Sicily (southern Italy, central Mediterranean Sea). Tectonophysics $422,23-40$.

Appraisal Institute, 2008. In: Appraisal Institute (Ed.), The Appraisal of Real Estate, thirteenth ed., pp. 20-25 Chicago.

Bartik, T.J., 1987. The estimation of demand parameters in hedonic price models J. Pol. Econ. 95 (11), 81-88.

Bengochea-Morancho, A., 2003. A hedonic valuation of urban green spaces. Landsc. Urban Plan. 66, 35-41.

Bolitzer, B., Netusil, N.R., 2000. The impact of open spaces on property values in Portland, Oregon. J. Environ. Manage. 59, 185-193.

Borrelli, L., Greco, R., Gullà, G., 2007. Weathering grade of rock masses as a predisposing factor to slope instabilities: reconnaissance and control procedure. Geomorphology 87, 158-175.

Borrelli, L., Perri, F., Critelli, S., Gullà, G., 2012. Minero-petrographical features of weathering profiles in Calabria, southern Italy. Catena 92, 196-207.

Borrelli, L., Perri, F., Critelli, S., Gullà, G., 2014. Characterization of granitoid and gneissic weathering profiles of the Mucone basin (Calabria, southern Italy). Catena 113, 325-340.

Brown, R.J., 1974. On the selection of the best predictive model in multiple regression analysis. Apprais. J. 4, 572-578.

Bruce, R.W., Sundell, D.J., 1977. Multiple regression analysis: history and application in the appraisal profession. Real Estate Apprais. 43 (1), 37-44.

Butler, R.W., 1996. The concept of carrying capacity for tourism destinations: dead or merely buried? Prog. Tour. Hosp. Res. 2 (3-4), 283-294.

Calcaterra, D., Parise, M., 2005. Landslide types and their relationships with weathering in a Calabrian basin, southern Italy. Bull. Eng. Geol. Environ. 64, 193-207.

Canestrelli, E., Costa, P., 1991. Tourism carrying capacity: a fuzzy approach. Ann. Tour. Res. 18 (2), 295-311.

Case, B., Quigley, J., 1991. The dynamics of real estate prices. Rev. Econ. Stat. 73 (1), $50-58$.

Chay, K.Y., Greenstone, M., 2004. Does Air Quality Matter? Evidence from the Housing Market (unpublished manuscript). University of California at Berkeley, MIT, NBER.

Chattopadhyay, S., 1999. Estimating the demand of air quality: new evidence based on the Chicago housing market. Land Econ. 75, 22-38.

Chiesura, A., 2004. The role of urban parks for the sustainable city. Landsc. Urban Plan. 68, 129-138.

Cortese, E. 1895. Descrizione geologica della Calabria. Mem. Descr. Car. Geol. Ital. 9, 89.

Cucci, L., Tertulliani, A., 2006. I terrazzi marini nell'area di Capo Vaticano (Arco Calabro): solo un record di sollevamento regionale o anche di deformazione cosismica? Il. Quat. 19, 89-101.

Davis, L.W., 2004. The effect of health risk on housing values: evidence from a cancer cluster. Am. Econ. Rev. 94 (5), 1693-1704.

Drèze, J.H., Hagen, H., 1978. Choice of product quality: equilibrium and efficiency. Econometrica 46, 496-513.

Dunford, R.W., Marti, L.E., Mittelhammer, R.C., 1985. A case study of rural land values at the urban fringe including subjective buyer expectation. Land Econ. 61, 10-16.

Garrod, G., Willis, K.G., 1992. Valuing goods characteristics: an application of the hedonic price method to environmental attributes. J. Environ. Manage. 34, 59-76.

Garrod, G., Willis, K.G., 1999. Economic Valuation of the Environment: Methods and Case Studies. Edward Elgar, Cheltenham, UK, p. 384.

Gayer, T., Hamilton, J.T., Viscusi, W.K., 2000. Private values of risk tradeoffs at superfund sites: housing market evidence on learning about risk. Rev. Econ. Stat. 82 (3), 439-451.

Geoghegan, J., 2002. The value of open spaces in residential land use. Land Use Policy 19, 91-98.

Ghisetti, F., 1980. Caratterizzazione dei blocchi della Calabria meridionale in base alla velocità di sollevamento nel Plio-Pleistocene: una proposta di zonazione neotettonica. Contributi alla realizzazione della Carta Neotettonica d'Italia C.N.R. Prog. Fin. Geod. 356, 775-809.

Girard, L.F., 1993. Estimo, economia ambientale e sviluppo sostenibile. In: Angeli, F (Ed.), Estimo ed economia ambientale: le nuove frontiere nel campo della valutazione, Milano, pp. 13-43.

Greco, P., Marconi, G. Rizzo, V., 1995. L'impatto antropico sull'erosione costiera - un caso emblematico: la costa dell'alto tirreno cosentino (Calabria settentrionale) In: Università della Calabria (Ed.), Ambiente e Turismo: un Equilibrio Multimodale, Arcavacata di Rende, pp. 315-321.

Hidano, N., 2002. The Economic Valuation of the Environment and Public Policy: a Hedonic Approach. Edward Elgar, Cheltenham, UK, p. 167.

Hoevenagel, R., 1994. A comparison of economic valuation methods. In: Pethig, R. (Ed.), Valuing the Environment: Methodological and Measurement Issues. Kluwer Academic, Amsterdam, pp. 251-272.

Howe, C.H., 1979. Natural Resource Economics: Issues, Analysis, and Policy. John Wiley \& Sons, New York.

Howe, C.W., 1993. Le frontiere nella valutazione di risorse prive di mercato: problemi e prospettive. In: Angeli, F. (Ed.), Estimo ed economia ambientale: le nuove frontiere nel campo della valutazione, Milano, pp. 57-83.

Ietto, A., Altomare, C., Donato, F.F., Federico, M., Ietto, F., Teti, F., 2003. The Miocenic cliff at the NW edge of Mesima sedimentary basin (Calabria, Southern Italy). Geogr. Fis. Dinam. Quart. 26, 143-145. 
Ietto, A., Ietto, F., 2004. Age and history of the weathering of granitoids in southern Calabria (Italy). Geogr. Fis. Dinam. Quat. 27, 37-45.

Ietto, F., Bernasconi, M.P., 2005. The cliff bordering the northwestern margin of the Mesima basin (southern Calabria) is of Pleistocene age. Geogr. Fis. Dinam. Quart. $28,205-210$

Ietto, F., Donato, F.F., Ietto, A., 2007. Recent reverse faults and landslides in granitoid weathered profiles, Serre Mountains (southern Calabria, Italy). Geomorphology 87 (3), 196-206.

Ietto, F. Talarico, F., Francolino, S., 2009. Cause dell'alluvione di Vibo Valentia de 2006 e caratteristiche dell'ambiente costiero dopo l'evento. Biol. Amb. 23 (1), 3-12.

Ietto, F., 2012. Cause dell'evento alluvionale del 19 ottobre 2010 nel bacino del Torrente della Grazia (Tropea, Calabria), Geol. Amb. 2, 195-199.

Ietto, F., Parise, M., Ponte, M., Calcaterra, D., 2012. Geotechnical characterization and landslides in the weathered granitoids of Calabria (southern Italy). Rend. Online Soc. Geol. It. 2, 551-553.

Ietto, F., Le Pera, E., Perri, F., 2013. Weathering of the 'Rupe di Tropea' (southern Calabria): consolidation criteria and erosion-rate estimate. Rend. Online Soc. Geol. It. 24, 178-180.

Ietto, F., Perri, F., Fortunato, G., 2014. Lateral spreading phenomena and weathering processes from the Tropea area (Calabria, southern Italy). Environ. Earth Sci. http://dx.doi.org/10.1007/s12665-014-3745-0 (in press).

International Valuation Standard Council, 2007. IVSC, London, p. 21.

Jim, C.Y., Chen, W.Y., 2006. Impacts of urban environmental elements on residential housing prices in Guangzhou (China). Land. Urban. Plan. 78, 422-434.

Kelleher, G., Kenchington, R., 1990. Guidelines for the Establishment of Marine Protected Areas. World Conservation Union, Gland, Switzerland, p. 19.

Lancaster, K.J., 1966. A new approach to consumer theory. J. Pol. Econ. 74, 132-157.

Leggett, C.G., Bockstael, N.E., 2000. Evidence of the effects of water quality on residential land prices. J. Environ. Econ. Manage. 39 (2), 121-144.

Luttik, J., 2000. The value of trees, water and open space as reflected by house prices in The Netherlands. Landsc. Urban Plan. 48, 161-167.

McConnell, V., Walls, M., 2005. The Value of Open Space: Evidence from Studies of Nonmarket Benefits. Resources for the Future, Washington, DC, p. 78.

Miyauchi, T., Dai Pra, G., Sylos- Labini, S., 1994. Geochronology of Plesitocene marine terraces and regional tectonics in Tyrrhenian coast of South Calabria, Italy. Il. Quat. 7, 17-34.

More, T.A., Stevens, T., Allen, P.G., 1988. Valuation of urban parks. Landsc. Urban Plan. 15, 139-152.

Moriani, G., 1991. In: Marsilio (Ed.), Manuale di ecocompatibilità. Venezia.

Nicotera, P. 1959. Rilevamento geologico del versante settentrionale del monte Poro (Calabria). Mem. Note Ist. Geol. Appl. 7, 1-92.

Nijkamp, P., 1993. Lo sviluppo sostenibile e la valutazione socio economica ed ambientale. In: Angeli, F. (Ed.), Estimo ed economia ambientale: le nuove frontiere nel campo della valutazione, Milano, pp. 281-304.

Novarese, V., 1931. La formazione dioritico-kinzgitica in Italia. Boll. R. Uff. Geol. It. 56 (7), 1-62.

Ouyang, T., Wang, B., 2003. A hedonic price function for a Northern BC community. Soc. Indic. Res. 61, 285-296.

Pagourtzi, E., Assimakopoulos, V., Hatzichristos, T., French, N., 2003. Real estate appraisal: a review of valuation methods. J. Prop. Invest. Financ. 21, $383-401$.
Pearce, D.G., Kirk, R.M., 1986. Carrying capacities for coastal tourism. UNEP Ind. Environ. 9 (1), 3-7.

Perri, F., Borrelli, L., Critelli, S., Gullà, G., 2012a. Investigation of weathering rates and processes affecting plutonic and metamorphic rocks in Sila Massif (Calabria, southern Italy). Rend. Online Soc. Geol. It. 21, 557-559.

Perri, F., Critelli, S., Dominici, R., Muto, F., Tripodi, V., Ceramicola, S., 2012b. Provenance and accommodation pathways of late Quaternary sediments in the deepwater northern Ionian Basin, southern Italy. Sed. Geol. 280, 244-259.

Perri, F., Scarciglia, F., Apollaro, C., Marini, L., 2014. Characterization of granitoid profiles in the Sila Massif (Calabria, southern Italy) and reconstruction of weathering processes by mineralogy, chemistry, and reaction path modeling. J. Soils Sed. http://dx.doi.org/10.1007/s11368-014-0856-x (in press).

Petrucci, O., Chiodo, G. Caloiero, D., 1996. CNR-IRPI, Pubbl. 1374. In: Rubbettino Art Grafiche (Ed.), Eventi Alluvionali in Calabria Nel Decennio 1971-1980. Sovera Mannelli, Catanzaro.

Powe, N.A., Garrod, G.D., Willis, K.G., 1995. Valuation of urban amenities using an hedonic price model. J. Prop. Res. 12, 137-147.

Price, C., 2003. Quantifying the aesthetic benefits of urban forestry. Urban For. Urban Green. 1, 123-133.

Romeril, M., 1990. Tourism Planning and the Concept of Carrying Capacity. UNEP, Paris.

Rosen, S., 1974. Hedonic prices and implicit markets: product differentiation in pure competition. J. Pol. Econ. 82 (1), 34-55.

Rosen, R., 1978. Fundamentals of measurement and representation of natural systems. In: Elseiver (Ed.), North-Holland Series in General Systems Research XVII. Amsterdam, New York.

Saderion, Z., Smith, B., Smith, C., 1994. An integrated approach to the evaluation of commercial real estate. J. Real Estate Res. 9 (2), 151-167.

Shafer, C.S., Lee, B.K., Turner, S., 2000. A tale of three greenway trails: user perceptions related to quality of life. Landsc. Urban Plan. 49, 163-178.

Sheppard, S., 1999. Hedonic analysis of housing markets. In: Cheshire, P., Mills, E.S. (Eds.), Handbook of Regional and Urban Economics, Applied Urban Economics, vol. 3. Elsevier, Amsterdam, pp. 1595-1635.

Simonotti, M., 2006. In: Dario Flaccovio (Ed.), Metodi di stima immobiliare. Palermo.

Stankey, G.H., 1984. Carrying capacity in recreational settings: evolution, appraisal, and application. Leis. Sci. 6 (4), 453-473.

Tajima, K., 2003. New estimates of the demand for urban green space: implications for valuing the environmental benefits of Boston's big dig project. J. Urban Aff. $25,641-655$.

Thomson, S.N., 1994. Fission track analysis of the crystalline basement rocks of the Calabrian Arc, southern Italy: evidence of Oligo-Miocene late-orogenic extension and erosion. Tectonophysics 238, 331-352.

Tortorici, G., Bianca, M., De Guidi, G., Monaco, C., Tortorici, L., 2003. Fault activity and marine terracing in the Capo Vaticano area (southern Calabria) during the Middle-Late Quaternary. Quatern. Intern. 102, 269-278.

Tyrväinen, L., Miettinen, A., 2000. Property prices and urban forest amenities. J. Environ. Econ. Manage. 39, 205-223.

Van Herzele, A., Wiedemann, T., 2003. A monitoring tool for the provision of accessible and attractive urban green spaces. Landsc. Urban Plan. 63, 109-126.

Willis, K.G. Garrod, G.D. 1993. The contribution of trees and woodland to the value of property. J. Arboric. 17, 211-219. 